\title{
Easily missed fracture: distal radius and concomitant proximal ulna
}

\author{
Sheena Seewoonarain, Majeed Shakokani, Stephen Pryke
}

Department of Trauma and Orthopaedics, Ipswich Hospital NHS Trust, Ipswich, Suffolk, UK

\section{Correspondence to} Sheena Seewoonarain, sseewoonarain@gmail.com

Accepted 27 January 2016
CrossMark

To cite: Seewoonarain S,
Shakokani M, Pryke S. BMJ
Case Rep Published online:
[please include Day Month
Year] doi:10.1136/bcr-2016-
214399

\section{DESCRIPTION}

An 8-year-old girl presented to the emergency department following a fall from a climbing frame onto her outstretched left hand. On examination, the left wrist was swollen and tender. The skin was intact with no neurovascular compromise. The patient also reported pain in the left elbow, which was tender on palpation. Anteroposterior and lateral radiographs of the left forearm showed a fracture of the distal radius and proximal ulna (figures 1 and 2).

The patient was placed in an above elbow backslab and reviewed by the orthopaedic team in the fracture clinic the following day, where the backslab was changed to a complete above elbow cast. At 1 month postinjury, it was changed to a futura splint. The patient made a full recovery.

The Galeazzi fracture, comprising of a distal radial shaft fracture with associated distal radioulna joint injury, and the Monteggia fracture, composed of a proximal third ulna fracture and radial head instability, have both been described extensively. ${ }^{12}$

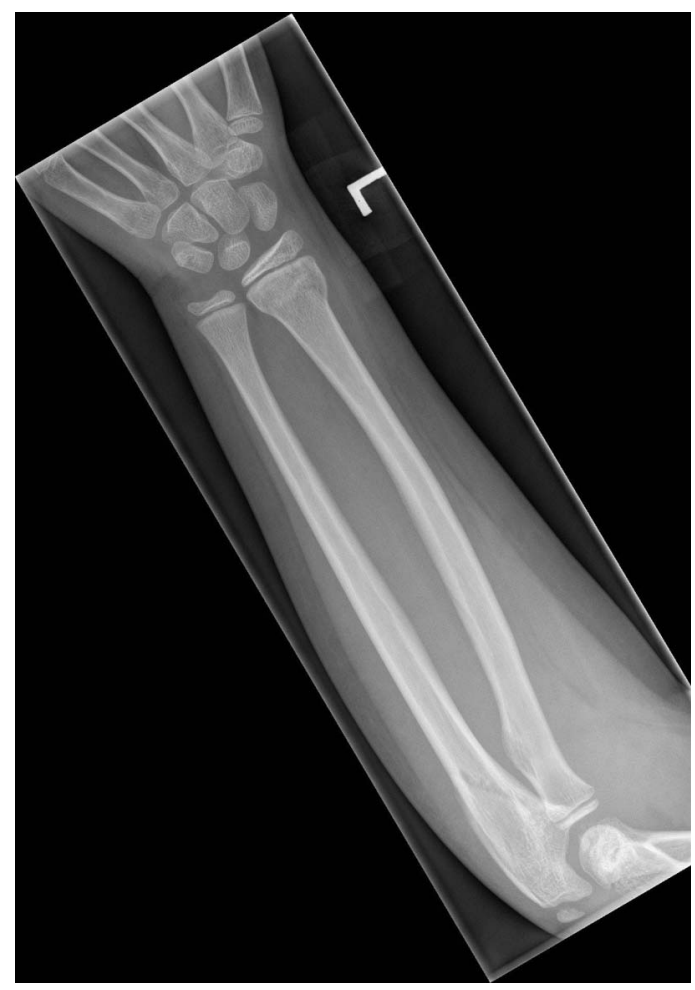

Figure 1 Anteroposterior radiograph of the left forearm showing a distal radius and proximal ulna fracture.

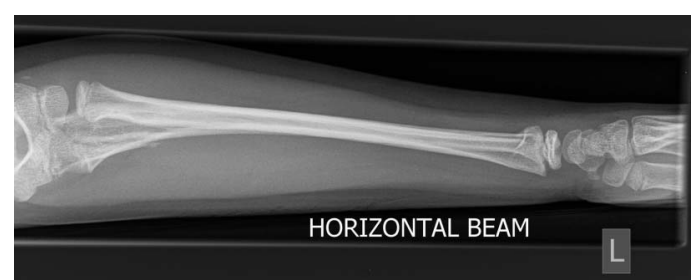

Figure 2 Lateral radiograph of the left forearm confirming a distal radius and proximal ulna fracture.

We present a rare combination of a fracture of the distal radius fracture and proximal ulna with limited review in the literature. ${ }^{3}$ This was not an unusual mechanism of injury and a distal radius fracture is a common presentation to the emergency department. Care should always be taken to perform a systematic examination, identify whether the injury is closed or open, look for the presence of any neurovascular deficit, and to examine the joint above and below. These factors are vital to making the correct diagnosis and management.

\section{Learning points}

- It is important to perform a systematic examination of any joint injury, including examination of the joint above and below, where appropriate.

- If there is high clinical suspicion of an associated long bone injury, a radiograph should include the joint, both above and below.

- Paediatric patients may be at risk of poor outcome if misdiagnosed.

Contributors SS contributed to the design and draft. MS and SP contributed to the concept and final review.

Competing interests None declared.

Patient consent Obtained.

Provenance and peer review Not commissioned; externally peer reviewed.

\section{REFERENCES}

1 Giannoulis FS, Sotereanos DG. Galeazzi fractures and dislocations. Hand Clin 2007:23:153-63, v.

2 Rehim SA, Maynard MA, Sebastin SJ, et al. Monteggia fracture dislocations: a historical review. J Hand Surg Am 2014;39:1384-94.

3 Gamie Z, Sehjal R, Lowery $\mathrm{K}$, et al. Ipsilateral complex distal radius fracture: a case report. 2014;22:1-6. 
Copyright 2016 BMJ Publishing Group. All rights reserved. For permission to reuse any of this content visit http://group.bmj.com/group/rights-licensing/permissions.

BMJ Case Report Fellows may re-use this article for personal use and teaching without any further permission.

Become a Fellow of BMJ Case Reports today and you can:

- Submit as many cases as you like

- Enjoy fast sympathetic peer review and rapid publication of accepted articles

- Access all the published articles

- Re-use any of the published material for personal use and teaching without further permission

For information on Institutional Fellowships contact consortiasales@bmjgroup.com

Visit casereports.bmj.com for more articles like this and to become a Fellow 